\title{
Cytochrome B Gene Partial Sequence and RAPD Analysis of Two Daphnia longispina Lineages Differing in their Resistance to Copper
}

\author{
N. Martins, ${ }^{1}$ I. Lopes, ${ }^{1}$ A. Brehm, ${ }^{2}$ R. Ribeiro ${ }^{1}$ \\ 1 Instituto do Ambiente e Vida, Departamento de Zoologia, Universidade de Coimbra, \\ Largo Marquês de Pombal, 3004-517 Coimbra, Portugal \\ 2 Departamento de Biologia, Universidade da Madeira, Campus da Penteada, \\ 9000-390 Funchal, Portugal
}

Received: 16 March 2004/Accepted: 19 January 2005

The loss of genetic diversity of populations exposed to environmental pollution is receiving growing attention among ecotoxicologists, with the increasing availability of easily applicable molecular techniques (van Straalen and Timmermans 2002). Several studies reported an association between contamination and genetic diversity. For instance, genetic variability reduction was found in populations of the isopod Platynympha longicaudata, the crustaceans Leander intermedius (Ross et al. 2002) and Balanus glandula (Ma et al. 2000), the mollusks Mytilus galloprovincialis (Ma et al. 2000) and Littorina brevicula (Kim et al. 2003), and the fish Ameiurus nebulosus (Silbiger et al. 2001), when subjected to various environmental contaminants. Furthermore, molecular techniques can be used to find and characterize markers that may be related to or confer a specific trait, such as the resistance to toxicants. Sturmbauer (1999), based on the 16 rDNA gene, differentiated oligochaete species differing in their cadmium resistance. Contaminant indicative band (CIB), obtained with the Random Amplified Polymorphic DNA (RAPD) technique, were found in plants (Mengoni et al. 2000) and fish (Nadig et al. 1998, Theodorakis 2001), even when no reduction in genetic diversity was found (Mengoni et al. 2000, Nadig et al. 1998). However, these bands, which may include quantitative trait loci (QTL) for metal tolerance, were not yet characterized. The molecular characterization of some metal responsive genes that confer metal resistance has been performed for a few invertebrate species (Baršyte et al. 1999, Beaty et al. 1998, Liao et al. 2002, Tanguy and Moraga 2001).

Lopes et al. (2003) demonstrated that the increased resistance of a Daphnia longispina population, historically stressed by acid mine drainage, was mainly due to the elimination of the most sensitive individuals, as tolerant ones were also present in a reference population, though in lower frequency. The ultimate goal of this research is to compare the genetic diversity of these populations, regarding both diversity in single genes and in the whole genome, and to identify genetic markers that could discriminate resistant from sensitive lineages. A first step, which is the objective of the present study, was to compare two cloned lineages, originated from reference and impacted populations and that differed in their genetically-determined resistance to lethal levels of copper. The choice fell on the characterization of a fragment of the Cytochrome B, a gene commonly

$\overline{\text { Correspondence to: }}$ R. Ribeiro 
used as a marker of population divergence and genetic diversity, and one of the few that were already characterized in other Daphnia species (Schwenk 1993). Furthermore, this work included the adaptation of the RAPD methodology for this species.

\section{MATERIALS AND METHODS}

The D. longispina O.F. Müller individuals used in this research belonged to cloned lineages derived from field-collected females of two natural populations: one inhabiting a site historically impacted with acid mine drainage and the other inhabiting a nearby reference (unpolluted) pond (Lopes et al. 2003). From each population, nearly 130 lineages were ranked according to their geneticallydetermined resistance to lethal levels of copper, after acclimation to laboratory conditions for at least 15 generations (Lopes et al. 2003). Lineages were maintained in ASTM hardwater medium (ASTM 2002), enriched with vitamins and the standard organic extract "Marinure 25" (Glenside, Stirling, UK), at $25 \pm$ $1^{\circ} \mathrm{C}$ under a $14: 10 \mathrm{hr}$ light:dark cycle. Daphnids were fed daily with Pseudokirchneriella subcapitata (Korshikov) Hindak (formerly known as Selenastrum capricornutum Printz) $\left(3 \times 10^{5}\right.$ cells $/ \mathrm{mL} /$ day $)$. The medium was changed every other day. For this study, two cloned lineages, differing on their genetically-determined resistance to lethal levels of copper, from the reference (R) and the impacted (I) populations were used. Respective values of copper $\mathrm{LC}_{50,48 \mathrm{hr}}$ (with the 95\% confidence interval) were $75.5(67-84)$ and $254.9(195-396) \mu \mathrm{g} / \mathrm{L}$ (Lopes et al. submitted).

Groups of 25 individuals from each lineage were placed in eppendorf tubes, dried by aspiration and manually homogenated in $25 \mu \mathrm{L}$ of ethanol, with a glass rod. Ethanol was left to evaporate prior to extraction. DNA extraction was performed according to the phenol/chloroform/isoamylic alcohol extraction protocol (Sambrook et al. 1989). One milliliter of phenol/chloroform/isoamylic alcohol $(25: 24: 1)$ solution was placed in the tubes and mixed with a vortex. Samples were centrifuged for $10 \mathrm{~min}$ at $10,000 \mathrm{rpm}$ in a microcentrifuge. Supernatant was then pipetted to new tubes, to which $500 \mu \mathrm{L}$ of cold $\left(4^{\circ} \mathrm{C}\right)$ isopropanol were added, centrifuged for another $10 \mathrm{~min}$ at $10,000 \mathrm{rpm}$, and resulting supernatant discarded. Then, $500 \mu \mathrm{L}$ of cold $\left(4^{\circ} \mathrm{C}\right)$ ethanol were added and centrifugation followed for another $10 \mathrm{~min}$ at $10,000 \mathrm{rpm}$. Supernatant (isopropanol) and most of the ethanol phase (lower phase) was carefully pippeted off, avoiding pellet disturbance. Excess ethanol was left to evaporate at room temperature. The pellet was then resuspended in $250 \mu \mathrm{L}$ of autoclaved nanopure nuclease-free water (NFW), and stored at $-20^{\circ} \mathrm{C}$.

In this work, a fragment of the cytochrome B (CytB) was sequenced accordingly to Brehm et al. (2001). Prior to sequencing, the target gene fragment was amplified by polymerase chain reaction (PCR), using standard primers corresponding to conserved sequences of the gene: $\mathrm{CytB} 1$ and $\mathrm{CytB} 2$, flanking $\mathrm{a} \approx$ 300 base pairs (bp) sequence near the 5' end of the gene: 5'-CCATCCAACATCTCAGCATGATGAAA-3' and 5'-CCCTCAGAATGATA 
TTTGTCCTCA-3', respectively (adapted from Kocher et al. 1989). The reaction mixture for the PCR consisted of $16.5 \mu \mathrm{L}$ of NFW, $3.5 \mu \mathrm{L}$ of $10 \mathrm{x}$ Taq DNA buffer (Amersham Pharmacia, Uppsalla, Sweden), $2 \mu \mathrm{L}$ of $\mathrm{Mg}^{2+}, 3 \mu \mathrm{L}$ of each oligonucleotide primer $(5 \mathrm{pmol} / \mu \mathrm{L}), 2 \mu \mathrm{L}$ of dNTP $\operatorname{mix}(2 \mathrm{mM}$ of each nucleotide; Promega, Charbonniéres, France), 1.5 units of Taq polymerase (Amersham Pharmacia), and $2.0 \mu \mathrm{L}$ of template DNA. Amplification was performed in a Biometra (Goettingen, Germany) thermocycler, and consisted of a 2-min denaturation phase at $96^{\circ} \mathrm{C}$, followed by 35 cycles of $30 \mathrm{sec}$ at $94^{\circ} \mathrm{C}, 30 \mathrm{sec}$ at $50^{\circ} \mathrm{C}$ and $30 \mathrm{sec}$ at $72^{\circ} \mathrm{C}$, followed by a final 5 -min extension phase at $72^{\circ} \mathrm{C}$. After amplification, the presence of PCR products was confirmed by running 10 $\mu \mathrm{L}$ of sample in an 1.2\%-agarose gel (Sigma, Munich, Germany), at $150 \mathrm{~V}$ for 45 min. Bands were visualized under UV light, after soaking in ethidium bromide (Sigma). For samples that successfully amplified, DNA was purified in Sephadex G-50 microcolumns (Sigma), by centrifugation during $4 \mathrm{~min}$ at $4,000 \mathrm{rpm}$. Afterwards, sequencing reaction proceeded with a second $\mathrm{PCR}$ reaction, in which fluorescent-labeled nucleotides and the $\mathrm{CytB} 1$ primer were added, producing antisense single stranded DNA chains. Reaction mixture for the second PCR consisted of $4.5 \mu \mathrm{L}$ of NFW, 3.0 $\mu \mathrm{L}$ of primer, $2.0 \mu \mathrm{L}$ of Big Dye (Applied Biosystems, Foster City, CA, USA), and $2.0 \mu \mathrm{L}$ of template DNA. Amplification reaction conditions were the same as for the previous reaction. After cleaning in Sephadex microcolumns, water was evaporated and $15 \mu \mathrm{L}$ of Template Supression Reagent (Applied Biosystems) were added to the DNA. Sequencing was performed in an Applied Biosystem 373 DNA sequencing apparatus. Obtained sequences were aligned and compared with published sequences using the online version of BLAST 2 (http://www.ncbi.nlm.nih.gov/blast/bl2seq/bl2; Tatusova and Madden 1999).

RAPD reactions were performed according to Freitas and Brehm (2001), using OpA3, OpA4, OpA5, OpA7, and OpA11 primers (Operon Technologies, Alameda, CA, USA). From these, only OpA3, OpA4 and OpA7 primers yielded good resolution banding patterns. To ensure the repeatability, RAPD reaction was repeated with these primers. The reaction mixture consisted of $12 \mu \mathrm{L}$ of NFW, 2 $\mu \mathrm{L}$ of 10x Taq DNA buffer, $2 \mu \mathrm{L}$ of $\mathrm{Mg}^{2+}, 2 \mu \mathrm{L}$ of the oligonucleotide primer (5 $\mathrm{pmol} / \mu \mathrm{L}$ ), $2 \mu \mathrm{L}$ of $\mathrm{dNTP}$ mix ( $2 \mathrm{mM}$ of each nucleotide), 1 unit of Taq polymerase, and $2 \mu \mathrm{L}$ of template DNA. Amplification was performed in a Biometra thermocycler, and consisted of a 2 -min denaturation phase at $96^{\circ} \mathrm{C}$, followed by 45 cycles of $1 \mathrm{~min}$ at $92^{\circ} \mathrm{C}, 1 \mathrm{~min}$ at $36^{\circ} \mathrm{C}$ and $2 \mathrm{~min}$ at $72^{\circ} \mathrm{C}$, followed by a final 3 -min extension phase at $72^{\circ} \mathrm{C}$. Amplified samples were kept at $4^{\circ} \mathrm{C}$ until being ran in a $1.2 \%$-agarose gel, at $180 \mathrm{~V}$ for $30 \mathrm{~min}$. Bands were detected under UV light, after soaking in ethidium bromide. The 100 base pair ladder (Amersham Pharmacia) was used as a molecular size marker.

\section{RESULTS AND DISCUSSION}

No genetic diversity was found for the CytB gene in the two lineages. The obtained sequence has 308 bases and is accessible via GenBank (http://www.ncbi.nlm.nih.gov/genbank), under accession number AY453690. It 


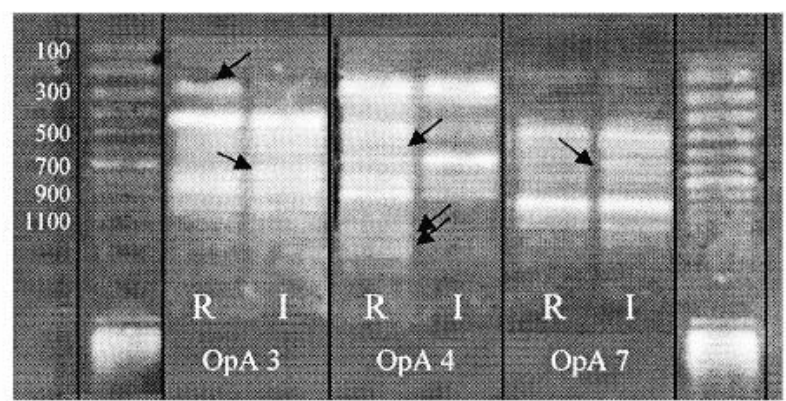

Figure 1. Random amplified polymorphic DNA profiles of the two studied Daphnia longispina cloned lineages, one sensitive (R) and one resistant (I) to copper contamination, using the OpA3, OpA4 and OpA7 primers. Arrows indicate differentially amplified bands. First and last lanes are the 100 base pairs DNA ladder.

presents $73 \%$ homology with the published sequence for the same gene of $D$. pulex (Weider et al. 1999) and 89\% for D. galeata (Schwenk 1993). The later author pointed out that, within the $D$. longispina subgroup species, CytB variability is very low, since species divergence is relatively recent. For this species, this author suggested the study of other faster evolving mtDNA regions, like the adenine-thymine rich region of the mitochondrial genome. Low variability for CytB was also found in a similar study by Dahl et al. (2001) in black crowned heron (Nycticorax nycticorax) populations subject to genotoxic contaminants. The authors referred that this low variability might have been due to a previous genetic bottleneck or to a high conservativeness of the gene in this species. Kim et al. (2003) found in a population of the gastropod L. brevicula, subjected to heavy metal pollution, a reduction in the variability of the ND6 gene when compared to a reference population, whereas for the $\mathrm{Cyt} B$ gene no genetic differences were found. This may indicate that the study of the ND6 gene could be more informative and relevant, regarding metal resistance, than the CytB gene, although this gene is commonly used in phylogenetic studies (Brehm et al. 2001, Schwenk 1993). Mitochondrial DNA haplotype polymorphisms enable to trace the genetic history or phylogenetic divergence of the studied populations. Populations along a pollution gradient should share an evolutionary history, rather than being polyphyletic, otherwise a convincing argument cannot be made that pollution adaptation has evolved within these populations. The study of mitochondrial haplotypes of $\mathrm{CytB}$ denoted that both populations probably share a common phyletic origin.

Obtained RAPD profiles are depicted in Figure 1. For the three primers with which good resolution banding patterns were obtained, RAPD profiles yielded at least one unshared band in each lineage. Probably due to a poor amplification with primer OpA4, lineage I yielded a smaller number of bands than lineage R. With primers OpA 3 and OpA7, all bands except one were common, having each lineage one specific band. Lineage specific (R- and I-) bands were the following: with primer OpA3, the 300-bp R-band and the 800-bp I-band; with primer OpA4, 
the 600- and the two >1100-bp R-bands; with primer OpA7, the 800-bp I-band. Although these differences have little biological significance, since it is unknown what genes, if any, they code for, this confirmed that each lineage corresponds to a different clone. Comparing the two used methodologies, RAPD analysis proved to be more useful than the direct $\mathrm{CytB}$ gene sequencing in discriminating the two lineages. However, other methodologies of whole-genome comparison, like AFLP or TE-AFLP (van Der Wurff et al. 2000), are to be considered in future works, as they are more robust and reproducible than RAPD analysis.

Acknowledgments. N. Martins and I. Lopes were recipients of grants from the Fundação para a Ciência e a Tecnologia / PRAXIS XXI. Authors would like to thank to H. Freitas, for technical assistance at the Universidade da Madeira.

\section{REFERENCES}

ASTM (2002) Standard guide for conducting acute toxicity tests on test materials with fishes, microinvertebrates, and amphibians. In: Annual Book of American Society of Testing and Materials Standards, vol 1105. Philadelphia, PA, USA, p 729-796

Baršyte D, White KN, Lovejoy DA (1999) Cloning and characterization of metallothionein cDNA in the mussel Mytilus edulis L. digestive gland. Comp Biochem Physiol C-Pharmacol Toxicol Endocrinol 122:287-296

Beaty BJ, Black WC, Carlson JO, Clements WH, DuTeau N, Harrahy E, Nuckols J, Kenneth E, Olson KE, Rayms-Keller A (1998) Molecular and genetic ecotoxicologic approaches to aquatic environmental bioreporting. Environ Health Perspect 106 Suppl 6:1395-1407

Brehm A, Jesus J, Pinheiro M, Harris DJ (2001) Relationships of scincid lizards (Mabuya spp; Reptilia: Scincidae) from the Cape Verde islands based on mitochondrial and nuclear DNA sequences. Mol Phylogenet Evol 19:311316

Dahl CR, Bickham JW, Wickliffe JK, Custer TW (2001) Cytochrome b sequences in black-crowned night-herons (Nycticorax nycticorax) from heronries exposed to genotoxic contaminants. Ecotoxicology 10:291-297

Freitas H, Brehm A (2001) Genetic diversity of the Macaronesian leafy liverwort Porella canariensis inferred from RAPD markers. J Hered 92:339-345

Kim S, Rodriguez-Lanetty M, Suh J, Song J (2003) Emergent effects of heavy metal pollution at a population level: Littorina brevicula a study case. Mar Pollut Bull 46:74-80

Kocher TD, Thomas WK, Meyer A, Edwards SV, Paabo S, Villablanca FX, Wilson AC (1989) Dynamics of mitochondrial DNA evolution in animals: amplification and sequencing with conserved primers. Proc Natl Acad Sci USA 86:6196-6200

Liao VH, Dong J, Freedman JH (2002) Molecular characterization of a novel, cadmium-inducible gene from the nematode Caenorhabditis elegans. A new gene that contributes to the resistance to cadmium toxicity. J Biol Chem 277:42049-42059

Lopes I, Baird DJ, Ribeiro R (submitted) Genetically-determined lethal resistance 
to copper by Daphnia longispina: association with sub-lethal responses and multiple/co-resistance. Environ Toxicol Chem

Lopes I, Baird DJ, Ribeiro R (2004) Genetic determination of tolerance to lethal and sub-lethal copper concentrations in field populations of Daphnia longispina. Arch Environ Contam Toxicol 46:43-51

Ma XL, Cowles DL, Carter RL (2000) Effect of pollution on genetic diversity in the bay mussel Mytilus galloprovincialis and the acorn barnacle Balanus glandula. Mar Environ Res 50:559-563

Mengoni A, Gonnelli C, Galardi F, Gabbrielli R, Bazzicalupo M (2000) Genetic diversity and heavy metal tolerance in populations of Silene paradoxa $\mathrm{L}$. (Caryophyllaceae): a random amplified polymorphic DNA analysis. Mol Ecol 9:1319-1324

Nadig SG, Lee KL, Adams SM (1998) Evaluating alterations of genetic diversity in sunfish populations exposed to contaminants using RAPD assay. Aquat Toxicol 43:163-178

Ross K, Cooper N, Bidwell JR, Elder J (2002) Genetic diversity and metal tolerance of two marine species: a comparison between populations from contaminated and reference sites. Mar Pollut Bull 44:671-679

Sambrook J, Fritsch EF, Maniatis T (1989) Molecular cloning: a laboratory manual. Cold Spring Harbor Press. New York, NY, USA

Schwenk K (1993) Interspecific hybridization in Daphnia: distinction and origin of hybrid matrilines. Mol Biol Evol 10:1289-1302

Silbiger RN, Leonard AC, Dimsoski P, Fore S, Guttman SI, Roth AC, Gordon DA, Wessendarp T, Toth GP, Smith MK (2001) Use of molecular markers to study the effects of environmental impacts on genetic diversity in brown bullhead (Ameirus nebulosus) populations. Environ Toxicol Chem 20:25802587

Sturmbauer C, Opadiya GB, Niederstatter H, Riedmann A, Dallinger R (1999) Mitochondrial DNA reveals cryptic oligochaete species differing in cadmium resistance. Mol Biol Evol 16:967-974

Tanguy A, Moraga D (2001) Cloning and characterization of a gene coding for a novel metallothionein in the Pacific oyster Crassostrea gigas (CgMT2): a case of adaptive response to metal-induced stress? Gene 273:123-130

Tatusova TA, Madden TL (1999) BLAST 2 sequences, a new tool for comparing protein and nucleotide sequences. FEMS Microbiol Lett 174:247-250

Theodorakis CW (2001) Integration of genotoxic and population genetic endpoints in biomonitoring and risk assessment. Ecotoxicology 10:245-256

van Der Wurff AW, Chan YL, van Straalen NM, Schouten J (2000) TE-AFLP: combining rapidity and robustness in DNA fingerprinting. Nucleic Acids Res 28:E105

van Straalen NM, Timmermans MJTN (2002) Genetic variation in toxicantstressed populations: an evaluation of the "genetic erosion" hypothesis. Hum Ecol Risk Assess 8:983-1002

Weider LJ, Hobaek A, Hebert PDN, Crease TJ (1999) Holarctic phylogeography of an asexual species complex - II. Allozymic variation and clonal structure in Arctic Daphnia. Mol Ecol 8:1-13 